\title{
Identification and characterization of phosphoenolpyruvate: fructose phosphotransferase systems in three Streptomyces species
}

\author{
Friedrich Titgemeyer, Jürgen Walkenhorst, Jonathan Reizer, \\ Maarten H. Stuiver, Xuewen Cui and Milton H. Saier, Jr
}

Author for correspondence: Milton H. Saier, Jr. Tel: +1 619534 4084. Fax: +1 6195347108.
e-mail: msaier@ucsd.edu

Department of Biology, University of California at San Diego, La Jolla, CA 92093-0116, USA

\section{Streptomyces lividans, S. coelicolor and S. griseofuscus were examined for the presence of the enzymes of the phosphoenolpyruvate:sugar phosphotransferase system (PTS). All three species were shown to possess Enzyme I, HPr and fructose-specific Enzyme II (IIFru) activities. In S. lividans and S. coelicolor, all three PTS enzymes were fructose-inducible, but in $S$. griseofuscus the system was expressed constitutively. These organisms apparently lack the HPr(Ser) kinase and HPr(Ser-P) phosphatase that characterize low-GC Gram-positive bacteria.}

Keywords: sugar transport, phosphorylation, phosphotransferase system, Streptomyces, regulation

\section{INTRODUCTION}

Streptomyces species are high-GC, Gram-positive, strictly aerobic soil actinomycetes. They differentiate with the development of fungal-like mycelia and spores (Schauer $e t$ al., 1988; Hodgson, 1992). They represent one of the most important groups of organisms for medical and industrial applications (Chater \& Hopwood, 1989, 1993) as they produce a diversity of antibiotics (Baltz \& Seno, 1988; Chater, 1990) and extracellular enzymes (Nagaso et al., 1988; McCarthy \& Williams, 1992; Strickler et al., 1992; Vats-Mehta et al., 1990). Differentiation and the production of secondary metabolites, including antibiotics, are regulated by interrelated, complex mechanisms (Hopwood, 1988; Hong et al., 1991; Distler et al., 1992; Geistlich et al., 1992; Ishizuka et al., 1992; Ueda et al., 1993). Moreover, these bacteria synthesize proteins that render them resistant to the antibiotics they produce. Horizontal transmission of the genetic material encoding these proteins is apparently in part responsible for the spread of drug resistance in bacterial populations (Mosher \& Vining, 1992; Parr \& Saier, 1992; Reizer et al., 1992b; Schoner et al., 1992). In order to understand the interrelationships between the syntheses of secondary metabolites and the metabolism of carbohydrates in these

Abbreviations: DTP, diphosphoryl transfer protein; -P, phosphate; PEP, phosphoenolpyruvate; PTS, phosphotransferase system; TMG, thiomethyl $\beta$-galactoside (methyl $\beta$-D-thiogalactopyranoside). bacteria, it is important to understand the pathways responsible for sugar catabolism (Martin \& Demain, 1980; Hodgson, 1982; Vilches et al., 1990; Delic et al., 1992).

The phosphoenolpyruvate: sugar phosphotransferase system (PTS) is known to function in carbohydrate transport, chemotaxis, and a variety of regulatory capacities in diverse bacteria (Reizer et al., 1988b; Titgemeyer, 1993). More than 20 different carbohydrates are transported via the PTS which exclusively uses phosphoenolpyruvate (PEP) as the phosphoryl donor in a phosphoryl transfer chain that involves the two general energy-coupling proteins, Enzyme I and HPr, as well as the sugar-specific, membrane-bound Enzyme II complexes. The Enzyme IIC permeases translocate the sugar substrates into the cytoplasmic compartment of the bacterial cell concomitant with phosphorylation (Saier \& Reizer, 1992; Postma et al., 1993).

Different types of regulatory phenomena such as catabolite repression, inducer exclusion and inducer expulsion have been described and characterized in enteric bacteria (Saier, 1989, 1993) and low-GC Gram-positive bacteria (Reizer et al., 1993; Ye et al., 1994a, b, c, d). In Gramnegative enteric bacteria, catabolite repression and the cytoplasmic levels of the inducing carbohydrates are regulated by the phosphorylation state of the IIA ${ }^{\text {Gle }}$ protein of the PTS (Saier, 1989; Saier \& Reizer, 1992). By contrast, in low-GC Gram-positive bacteria, an ATP- 
dependent protein kinase that phosphorylates HPr of the PTS on seryl residue 46 is involved in the regulation of similar physiological processes (Ye et al., 1994a, b, c, d). Moreover, in Gram-negative bacteria, PTS proteins apparently play regulatory roles in nitrogen utilization (Reizer et al., 1992a) and $\beta$-hydroxybutyrate production (Pries et al., 1991).

Although species of Streptomyces are able to utilize a large number of sugars for growth (Hodgson, 1980, 1982), knowledge concerning the pathways of carbohydrate metabolism and their regulation is still limited (Romano, 1986). Inducible or constitutive uptake has been reported for several sugars (Sabater et al., 1972; Sabater \& Asensio, 1973; Hodgson, 1982). Bacteria utilizing glucose, mannose and fructose exhibit activities for ATP-dependent glucokinase, fructokinase and mannokinase (Sabater et al., 1972; Ikeda et al., 1984; Angell et al., 1992) suggesting that transport systems for these sugars are not of the PTS type. At least five different groups have reported evidence leading to the conclusion that the PTS is lacking from the genus Streptomyces (Sabater et al., 1972; Romano \& Margiotta, 1980; Novotna \& Hostálék, 1985; GarciaDominguez et al., 1989; L. Dijkhuizen, personal communication in Angell et al., 1992). However, the PTS has been reported to be present in numerous low-GC Grampositive bacteria (Reizer et al., 1988a; Hoischen et al., 1993; Mitchell et al., 1993). It has also been found in a few high-GC Gram-positive bacteria including Artbrobacter pyridinolis, $A$. ureafaciens, Corynebacterium glutamicum and Brevibacterium belvolum (Reizer et al., 1988a; V. P. Juban, L.-F. Wu, J. Reizer, C. Blanco \& M. H. Saier, Jr, unpublished results). We have therefore re-examined the possibility that Streptomyces species possess a PTS by assaying for the presence of individual components of the system in three species of this genus. We chose $S$. coelicolor A3(2) and S. lividans TK23, which are genetically well characterized, as well as $S$. griseofuscus C581, a distantlyrelated fast-growing streptomycete. Our studies have led to the identification of two general energy-coupling proteins of the PTS, Enzyme I and HPr (Titgemeyer et al., 1994), as well as fructose-specific Enzyme II complexes in all three strains examined. The properties of these PTSs are presented, and the system in S. griseofuscus is shown to differ significantly from those in S. coelicolor and S. lividans.

\section{METHODS}

Materials. These were commercially obtained and were of the highest purity available. $\left[{ }^{14} \mathrm{C}\right]$ Fructose was purified free of anionic radioactive impurities by ion-exchange chromatography employing Bio-Rad AG1X2 (50-100 mesh) as described previously (Kundig \& Roseman, 1971; Saier et al., 1976).

Bacterial strains and growth conditions. S. lividans TK23, S. coelicolor A3(2)T2 and S. griseofuscus C581 were obtained from P. Solenberg and J. Tang (Eli Lilly Research Labs, Lilly Corporate Center, Indianapolis, IN 46285, USA). For preparation of crude cell extracts as well as cytoplasmic and membrane fractions, all three Streptomyces strains were grown for $24-72 \mathrm{~h}$ with vigorous shaking at $37^{\circ} \mathrm{C}(500 \mathrm{ml}$ volumes in 21 Erlenmeyer flasks) in tryptic soy broth without dextrose (Difco). Sugars, when present, were added to a final concentration of $0.4 \%$. Cells were harvested by centrifugation in the early stationary phase of growth.

Growth responses to various carbon sources were recorded using salts medium 63 (Miller, 1972; Sabater et al., 1972) containing $1 \%(\mathrm{w} / \mathrm{v})$ carbohydrate and $15 \mathrm{mM}$ asparagine (Vilches et al., 1990). Of the carbon sources tested, all three Streptomyces strains were found to utilize fructose and glucose most avidly. Mannitol, galactose, xylose, raffinose, glycerol and succinate were also used by all three strains. Maltose and melibiose were utilized by $S$. coelicolor and $S$. lividans but not by S. griseofuscus. Glucitol was not utilized to an appreciable extent by any of these Streptomyces species after $3 \mathrm{~d}$ vigorous shaking at $37^{\circ} \mathrm{C}$.

PEP- and ATP-dependent in vitro phosphorylation experiments. Cell-free extracts were prepared by passage of washed cells through a French press at 10000 p.s.i. $(69 \mathrm{kPa})$ and stored in aliquots at $-70^{\circ} \mathrm{C}$ in $20 \mathrm{mM}$ Tris/ $\mathrm{HCl}, \mathrm{pH} 7.5,3 \mathrm{mM}$ dithiothreitol, $0 \cdot 1 \mathrm{mM}$ phenylmethylsulfonyl fluoride (PMSF). Enzyme I and HPr were assayed by measuring [metbyl$\left.{ }^{14} \mathrm{C}\right]$ methyl $\beta$-D-thiogalactopyranoside $\left(\left[{ }^{14} \mathrm{C}\right] \mathrm{TMG}\right)$ phosphorylation in the presence of complementing mutant extracts of Staphylococcus aureus that express the lactose operon constitutively but lack either Enzyme I or HPr, respectively [strains S710A ( $p t s I)$ or S797A ( $p t s H)$, respectively]. The assay procedure of Kundig \& Roseman (1971), as modified by Saier $e t$ al. (1977), was used with $\left[{ }^{14} \mathrm{C}\right] \mathrm{TMG}(10$ or $20 \mu \mathrm{M})$ at a specific activity of $5 \mu \mathrm{Ci} \mu \mathrm{mol}^{-1}\left(185 \mathrm{kBq} \mu \mathrm{mol}^{-1}\right)$. The fructose-specific Enzyme II (II Fru $)$ preparations were assayed for PEP-dependent and ATP-dependent phosphorylation reactions using dialysed crude extracts of the three Streptomyces strains, while salt-washed membranes were used for the assay of fructose-1-P- $\left[{ }^{14} \mathrm{C}\right]$ fructose transphosphorylation activities essentially as described previously (Saier et al., 1977).

The salt-washed membranes used for assay of fructose-1$\mathrm{P}:\left[{ }^{14} \mathrm{C}\right]$ fructose transphosphorylation activity were prepared by a modification of the procedure of Borkovich \& Simon (1991). Membranes were washed twice by suspension and centrifugation with a solution containing $20 \mathrm{mM}$ Tris $/ \mathrm{HCl}, \mathrm{pH} 7 \cdot 5$, $3 \mathrm{mM}$ dithiothreitol, $0 \cdot 1 \mathrm{mM}$ PMSF and $2 \mathrm{M} \mathrm{KCl}$. The washed membranes were centrifuged at $200000 \mathrm{~g}$ for $30 \mathrm{~min}$ at $4{ }^{\circ} \mathrm{C}$, resuspended to a final protein concentration of between 20 and $40 \mathrm{mg} \mathrm{ml}^{-1}$ in the same solution lacking $\mathrm{KCl}$ and stored at $-70^{\circ} \mathrm{C}$. $\left[{ }^{14} \mathrm{C}\right]$ Fructose $\left(20 \mu \mathrm{M}\right.$; specific activity $5 \mu \mathrm{Ci} \mu \mathrm{mol}^{-1}$, $185 \mathrm{kBq} \mu \mathrm{mol}^{-1}$ ) was used for these assays. Phosphorylation of $\left[{ }^{14} \mathrm{C}\right]$ mannitol, methyl $\alpha-\left[{ }^{14} \mathrm{C}\right]$ glucoside, 2-deoxy $\left[{ }^{14} \mathrm{C}\right]$ glucose and $\left[{ }^{14} \mathrm{C}\right]$ glucose (all at $5 \mu \mathrm{Ci} \mu \mathrm{mol}^{-1}$ ) was assayed employing the same conditions. [ $\left.{ }^{32} \mathrm{P}\right]$ PEP- and $\left[{ }^{32} \mathrm{P}\right] \mathrm{ATP}$-dependent phosphorylation of Streptomyces PTS proteins or of purified PTS proteins from Bacillus subtilis was measured as described by Reizer et al. (1984, 1989). The specific activities of these two radioactive substrates were approximately $500 \mu \mathrm{Ci} \mu \mathrm{mol}^{-1}$

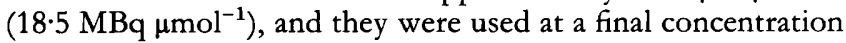
of $0.2 \mathrm{mM}$. Protein was determined by the method of Bradford (1976). Additional experimental details are provided in the legends to the figures and tables.

Partial purification of Enzyme I and HPr. Gel filtration was performed on French-pressed extracts derived from fructosegrown cells of the three Streptomyces species. A membrane-free extract of $0 \cdot 1 \mathrm{ml}\left(3-5 \mathrm{mg}\right.$ protein $\left.\mathrm{ml}^{-1}\right)$ was loaded onto a Superose 6 HR10/30 column attached to a Pharmacia FPLC system. Proteins were eluted with a buffer containing $20 \mathrm{mM}$ Tris $/ \mathrm{HCl}, \mathrm{pH} \mathrm{7.5}, 3 \mathrm{mM}$ dithiothreitol, $0.1 \mathrm{mM}$ PMSF and $15 \mathrm{mM} \mathrm{KCl}$. The flow rate was $0.5 \mathrm{ml} \mathrm{min}^{-1}$, and fractions of $0.2 \mathrm{ml}$ were collected. For the determination of the molecular masses of Enzyme I and HPr of the three Streptomyces species, 
Table 1. Identification of Enzyme I and HPr in extracts of three Streptomyces species by complementation assays

$p t s H$ and $p t s I$ mutant extracts of Staph. aureus were used at $130 \mu \mathrm{g}$ protein for the $p t s H$ extract and $90 \mu \mathrm{g}$ protein for the ptsI extract per assay solution of $100 \mu \mathrm{l}$, with the Streptomyces extracts present in limiting amounts (10-600 $\mu \mathrm{g}$ protein). The Streptomyces extracts were prepared from cells grown either with $(+)$ or without $(-)$ fructose. Values were determined in triplicate and varied from the mean by less than $10 \%$.

\begin{tabular}{|c|c|c|c|c|}
\hline \multirow[t]{2}{*}{ Enzyme assayed } & \multirow[t]{2}{*}{$\begin{array}{l}\text { Complementing } \\
\text { Staph. aureus extract }\end{array}$} & \multirow[t]{2}{*}{ Streptomyces extract } & \multicolumn{2}{|c|}{$\begin{array}{c}\text { Phosphorylation activity } \\
{\left[\mathrm{pmol}\left[{ }^{14} \mathrm{C}\right] \mathrm{TMG}-\mathrm{P} \mathrm{min}^{-1}(\mathrm{mg} \text { protein })^{-1}\right]}\end{array}$} \\
\hline & & & - Fructose & + Fructose \\
\hline & & S. coelicolor & $\leqslant 2$ & $\leqslant 2$ \\
\hline & & S. lividans & $\leqslant 2$ & $\leqslant 2$ \\
\hline & & S. griseofusucus & $\leqslant 2$ & $\leqslant 2$ \\
\hline & $p t s H$ & & $\leqslant 2$ & \\
\hline & $p t s I$ & & $\leqslant 2$ & \\
\hline & $p t s I+p t s H$ & & 1200 & \\
\hline \multirow[t]{3}{*}{ Enzyme I } & $p t s I$ & S. coelicolor & 90 & 730 \\
\hline & $p t s I$ & S. lividans & 100 & 410 \\
\hline & $p t s I$ & S. griseofuscus & 50 & 110 \\
\hline \multirow[t]{3}{*}{$\mathrm{HPr}$} & $p t s H$ & S. coelicolor & $\leqslant 2$ & 27 \\
\hline & $p t s H$ & S. lividans & $\leqslant 2$ & 20 \\
\hline & $p t s H$ & S. griseofuscus & $\leqslant 2$ & 17 \\
\hline
\end{tabular}

standard marker proteins were run separately under the same conditions.

\section{RESULTS}

\section{Complementation assays for Enzyme I and HPr}

Table 1 presents the results of complementation assays for the two energy-coupling proteins of the PTS, Enzyme I and HPr. The three Streptomyces extracts exhibited no detectable TMG phosphorylation activity in the presence of PEP [ 2 pmol TMG-P formed $\mathrm{min}^{-1}$ ( $\mathrm{mg}$ protein $)^{-1}$ ] (Table 1 ). The $S$. aureus $p t s H$ and $p t s I$ mutant extracts alone exhibited negligible activity; when these two mutant extracts were mixed, a high level of activity was observed (Table 1). Addition of extracts from brothgrown cultures of any one of the Streptomyces strains gave low activity for Enzyme I and non-detectable activity for HPr (Table 1). Growth in the presence of fructose enhanced both activities in all three Streptomyces species. The inductive effect of fructose on Enzyme I activity was maximal for $S$. coelicolor and minimal for $S$. griseofuscus (Table 1).

\section{Fractionation of Enzyme I and HPr}

Membranes were removed from the extracts by centrifugation, and the Enzyme I and $\mathrm{HPr}$ activities were shown to reside in the soluble fractions. These were passed through a calibrated gel filtration column. Extracts of all three Streptomyces strains exhibited HPr activities that eluted in the same position (estimated molecular mass $11 \mathrm{kDa}$ ). The S. lividans and S. coelicolor Enzymes I both eluted with an apparent molecular mass of $130 \mathrm{kDa}$ $( \pm 10 \%)$ as expected for dimeric Enzyme I, but the $S$. griseofuscus Enzyme I eluted as a protein of $70 \mathrm{kDa}$ $( \pm 15 \%)$ as expected for monomeric Enzyme I (Grenier $e t$ al., 1985). Since all three extracts were prepared in the same way, the results suggest a difference between the $S$. griseofuscus Enzyme I and those from $S$. lividans and $S$. coelicolor. It is worth noting that the latter two species are believed to be closely related while $S$. griseofuscus is more distant.

\section{[32P]PEP-dependent protein phosphorylation assays}

The identity of Enzyme I and HPr in Streptomyces was confirmed by [ $\left.{ }^{32} \mathrm{P}\right] \mathrm{PEP}$-dependent protein phosphorylation assays employing the protein fractions that were partially purified by gel filtration. As shown in Fig. 1 for $S$. lividans, a protein corresponding in position to Enzyme I from Bacillus subtilis could be phosphorylated with $\left[{ }^{32} \mathrm{P}\right] \mathrm{PEP}$ as the phosphoryl donor in the absence of any other protein fraction (lane 1). The Streptomyces Enzyme I could phosphorylate B. subtilis HPr (lane 2).

In lanes 5, 10 and 11 of Fig. 1, additional bands migrate just below the band corresponding to Enzyme I of $S$. lividans. These are most probably degradation products of Enzyme I. Such degradation products have been observed previously in other bacteria (LiCalsi et al., 1991). S. lividans HPr was not phosphorylated by $\left[{ }^{32} \mathrm{P}\right] \mathrm{PEP}$ unless $B$. subtilis or S. lividans Enzyme I was added (Fig. 1, lanes 3-5, 10, 11). Two phosphorylated protein bands appeared in the size range between 7 and $15 \mathrm{kDa}$, as expectd for $\mathrm{HPr}$ proteins (Reizer et al., 1988a). One co-migrated with $B$. subtilis $\mathrm{HPr}$ while the other migrated slightly faster in the SDS gels. The presence of two bands could be explained either by the presence of two distinct species of $\mathrm{HPr}$ 


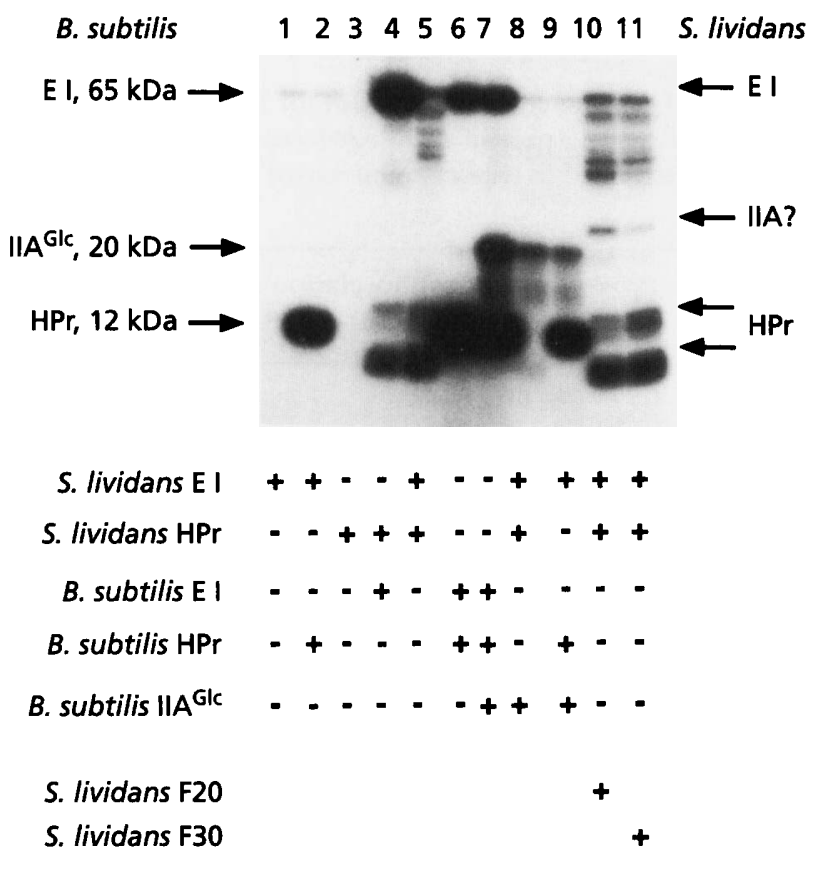

Fig. 1. Phosphorylation of partially purified protein fractions from S. lividans and of homogeneous $B$. subtilis proteins using [32P]PEP as the phosphoryl donor. The S. lividans Enzyme I and $\mathrm{HPr}$ were partially purified by gel filtration as described in Methods. B. subtilis proteins were purified to homogeneity as described previously (Reizer et al., 1984, 1989). Protein additions were as indicated below the figure (F20, fraction from the gel filtration column of approximate molecular mass $20 \mathrm{kDa}$; F30, fraction from the gel filtration column of approximate molecular mass $30 \mathrm{kDa}$ ). The positions of standard $B$. subtilis Enzyme I, IIA Gle and HPr are indicated to the left of the figure. Positions of S. lividans Enzyme I, IIA? and HPr are indicated to the far right of the figure.

proteins or by partial proteolytic degradation of a single HPr protein.

S. lividans Enzyme I and HPr phosphorylated the glucosespecific Enzyme IIA of B. subtilis (IIA ${ }^{\text {Gle }}$; Fig. 1, lane 8), and the same phosphorylated protein was observed when $S$. lividans Enzyme I was added to the IIA ${ }^{\text {Glc }}$ protein with B. subtilis HPr (lane 9). These results show that the $B$. subtilis and $S$. livians PTS proteins exhibit crossreactivities. In lanes 10 and $11, S$. lividans fractions containing proteins in the size range $20-30 \mathrm{kDa}(\mathrm{F} 20$, lane 10) and $30-40 \mathrm{kDa}(\mathrm{F} 30$, lane 11) were detected in the presence of S. lividans Enzyme I and HPr. At least one protein band (IIA?, lane 10) was phosphorylated, migrating just above the band corresponding to the IIA ${ }^{\mathrm{Glc}}$ protein of B. subtilis. This may correspond to a Streptomyces IIA protein.

The partially purified Enzyme I of $S$. coelicolor was examined with respect to its capacity to phosphorylate various purified $\mathrm{HPr}$ and $\mathrm{HPr}$-like proteins (data not shown). It could phosphorylate HPr proteins of B. subtilis and $S$. coelicolor as well as the diphosphoryl transfer protein [DTP; FruB(MH)] of Salmonella typhimurium (Sutrina et al., 1988; Wu et al., 1990). The phosphorylated
$\mathrm{HPr}$ of $S$. coelicolor co-migrated with one of the two putative S. lividans phospho- $\mathrm{HPr}$ proteins as well as phospho-HPr of B. subtilis (see Fig. 1). The HPr of Escherichia coli was not phosphorylated under the same conditions. These results suggest that the $S$. coelicolor Enzyme I exhibits specificity with respect to its phosphoryl transfer activity. It prefers Gram-positive HPr or the fructose-specific HPr domain (FPr) of the enteric bacterial DTP to the general HPr protein of enteric organisms. This last observation is consistent with the probable specificity of the Streptomyces PTS for fructose.

\section{Apparent absence of HPr(Ser) kinase in the Streptomyces spp.}

All low-GC Gram-positive bacteria so far examined possess the metabolite-activated protein kinase that transfers the $\gamma$-phosphoryl moiety of ATP to serine- 46 of the PTS phosphocarrier protein, $\mathrm{HPr}$ (Deutscher \& Saier, 1983; Reizer et al., 1988b). This kinase is believed to function in catabolite repression, regulation of the activities of sugar: $\mathrm{H}^{+}$symport permeases, regulation of a cytoplasmic sugar-phosphate phosphatase and regulation of the activities of the PTS itself (Saier $e t$ al., 1994; Ye $e t$ al., 1994a, b, c, d). As a result of the latter three processes, it regulates cytoplasmic inducer accumulation. We examined the three species of Streptomyces for the presence of this enzyme by incubating $\left[\gamma^{32} \mathrm{P}\right]$ ATP with cell-free extracts of these bacteria under a variety of conditions. The possibility of phosphorylation of endogenous Streptomyces $\mathrm{HPr}$ and the heterologous, exogenously added $B$. subtilis HPr was tested in the presence and absence of the various metabolites (fructose 1,6-diphosphate, gluconate 6-phosphate and 2-phosphoglycerate) that activate the kinase in low-GC Gram-positive bacteria. Surprisingly, phosphorylation of HPr could not be detected, even though other proteins in the extracts became phosphorylated. Positive controls established that under the same conditions, the kinase of $B$. subtilis exhibited the expected activities.

\section{PEP- and ATP-dependent sugar phosphorylation}

Attempts were made to demonstrate convincing PEPdependent phosphorylation of various radioactive sugars. These sugars were selected based on the ability of the three Streptomyces species to utilize sugars (see Methods). PEP-dependent phosphorylation experiments were conducted in order to identify PTS activities towards fructose, glucose and mannitol. The fructose PTS is most widely distributed and may be the archetypal system (Saier et al., 1985) while th - ' ucose- and mannitol-specific systems are common to $\mathrm{r}$, Gram-negative and Grampositive bacteria. The radioactive sugars used were glucose, methyl $\alpha$-glucoside, 2-deoxyglucose, mannitol and fructose, and cells were grown in nutrient medium without a sugar or in the presence of glucose, fructose or mannitol. No phosphorylation was observed when methyl $\alpha$-glucoside was the phosphoryl acceptor. When glucose or 2-deoxyglucose was the phosphoryl acceptor, no stimulation over background was observed when PEP 
Table 2. PEP- and ATP-dependent phosphorylation of $\left[{ }^{14} \mathrm{C}\right]$ fructose in dialysed extracts of Streptomyces species grown with and without fructose

In vitro phosphorylation of $\left[{ }^{14} \mathrm{C}\right]$ fructose was carried out for $20 \mathrm{~min}$ at $37^{\circ} \mathrm{C}$ using $80 \mu \mathrm{g}$ protein of membrane-free cytoplasmic extract combined with $8 \mu \mathrm{g}$ of membrane fraction per assay solution of $100 \mu$ l. Activity was detected only when PEP or ATP was present ( $50 \mathrm{mM}$ final concentration). Values were determined in triplicate and varied from the mean by less than $10 \%$. PEP-dependent phosphorylation activities decreased rapidly when extracts were stored on ice for longer than $20 \mathrm{~min}$, while ATP-dependent phosphorylation activity remained stable. Therefore, PEP-dependent phosphorylation was assayed immediately after thawing of the extracts.

\begin{tabular}{|c|c|c|c|}
\hline \multirow[t]{3}{*}{$\begin{array}{l}\text { Streptomyces } \\
\text { species }\end{array}$} & \multirow[t]{3}{*}{$\begin{array}{l}\text { Sugar present } \\
\text { during growth }\end{array}$} & \multicolumn{2}{|c|}{$\begin{array}{l}\text { Phosphorylation } \\
\text { activity } \\
\text { [pmol fructose-P } \\
\text { min }^{-1} \\
{\text { (mg protein })^{-1} \text { ] }}^{\text {(mg }}\end{array}$} \\
\hline & & \multicolumn{2}{|c|}{ Phosphoryl donor: } \\
\hline & & PEP & ATP \\
\hline \multirow[t]{2}{*}{ S. lividans } & None & 0 & 61 \\
\hline & Fructose & 36 & 71 \\
\hline \multirow[t]{2}{*}{ S. coelicolor } & None & 1.5 & 12 \\
\hline & Fructose & 41 & 40 \\
\hline \multirow[t]{2}{*}{ S. griseofuscus } & None & $2 \cdot 5$ & 15 \\
\hline & Fructose & 4 & 10 \\
\hline
\end{tabular}

was added, although A TP strongly stimulated phosphorylation. With mannitol as the phosphoryl acceptor, activity over background was again observed only when ATP was added. By contrast, when fructose was used as the substrate, phosphorylation was observed when either PEP or ATP was added, and in S. lividans and S. coelicolor, the PEP-dependent activity was inducible by growth in the presence of fructose (Table 2). In S. lividans and $S$. griseofuscus, ATP-dependent fructose phosphorylation activity was expressed constitutively, while in $S$. coelicolor it was inducible. In several experiments, the PEP-dependent activity was as much as twofold higher than the ATPdependent activity, and increasing the ratio of membrane protein to soluble protein tended to increase the PEPdependent activity relative to the ATP-dependent activity (data not shown).

The ATP-dependent fructose phosphorylation activity proved to reside in the soluble fraction of the extract, while the PEP-dependent activity required both the soluble and the membrane fractions (data not shown). This observation suggested that a fructose-inducible, fructose-specific Enzyme II might be present in the membranes of these Streptomyces species. In order to confirm the presence of fructose Enzyme II activity in the Streptomyces extracts, the highly specific transphosphorylation assay was applied to salt-washed membrane preparations derived from cells grown with and without fructose. Fructose-1-P: $\left[{ }^{14} \mathrm{C}\right]$ fructose transphosphorylation activity was assayed as a function of $\mathrm{pH}$ (Fig. 2). Both $S$. coelicolor and S. lividans exhibited fructose-inducible transphosphorylation activities (up to fivefold induction; Figs 2a and b) while $S$.griseofuscus exhibited low activity that was weakly fructose-repressible (Fig. 2c). These results are in general agreement with the PEP-dependent phosphorylation results presented in Table 2 . No detectable transphosphorylation activity was observed when fructose-1-P was replaced by fructose-6-P, glucose-6-P or glucose-1-P in all three species examined (data not shown). This fact is reflective of the phosphoryl acceptor/donor specificity of the fructose-specific fructose-1-P-forming Enzymes II in other bacteria (see, for example, Mitchell et al., 1993).

\section{DISCUSSION}

The observations reported above demonstrate the presence of a fructose-specific PTS consisting of Enzyme I, $\mathrm{HPr}$ and a fructose-1-phosphate-forming Enzyme II complex in three species of Streptomyces. Other sugarspecific proteins of the PTS such as those comprising Enzyme II complexes specific for glucose and mannitol are probably not present.

In previous reports several groups failed to detect the PTS in species of Streptomyces (see Introduction). In contrast to these reports we have used approaches that
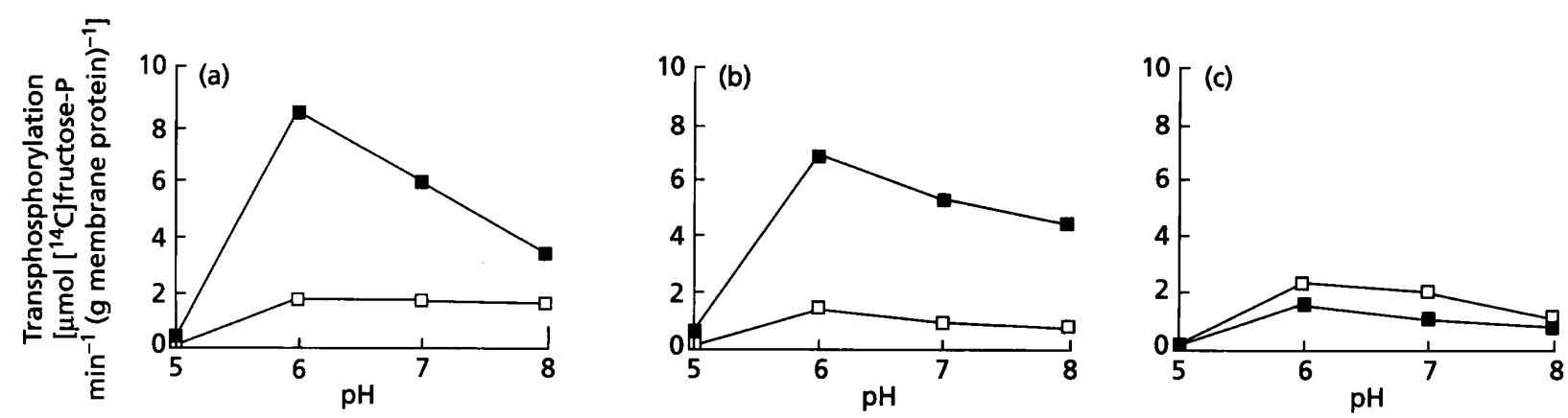

Fig. 2. Activity/pH profiles for the fructose-1-P: $\left[{ }^{14} \mathrm{C}\right]$ fructose transphosphorylation reaction measured with salt-washed membranes from (a) S. coelicolor, (b) S. lividans and (c) S. griseofuscus grown in the presence ( $\square$ ) or absence ( $\square$ ) of fructose. Membrane preparation and assay procedures were as described in Methods. 
allowed us to assay for the individual components of the PTS phosphoryl transfer chain. Evidence for the presence of Enzyme I and HPr could be easily obtained using the complementation assay with defined Stapbylococcus aureus mutants described in previous publications (Reizer et al., 1988a; Mitchell et al., 1993). The presence of a fructosespecific Enzyme II was clearly established by the detection of fructose-inducible PEP-dependent phosphorylation activity as well as fructose: fructose-1-P transphosphorylation activity.

Sabater et al. (1972) reported ATP-dependent phosphorylation of fructose, but they were unable to detect PEP-dependent phosphorylation of fructose in cell extracts of $S$. violaceoruber, which is genetically very closely related to $S$. lividans and $S$. coelicolor. Since we found that the PEP-dependent phosphorylation activity was unstable, losing activity when extracts were kept longer than $2 \mathrm{~h}$ at $0{ }^{\circ} \mathrm{C}$, it is possible that protease activities in the Streptomyces extracts accounted for the negative results reported by Sabater et al. (1972). In S. aureofaciens, both PEP- and ATP-dependent fructose phosphorylation activities have been reported by Novotna \& Hostálék (1985). The nonlinear kinetics of PEP-dependent phosphorylation activity, and the inability to detect fructose-1phosphate kinase activity, led these investigators to conclude that a PTS is not operative. When we assayed for the activity of fructose-1-P kinase in Streptomyces crude extracts, we detected weak activity employing conditions that were optimal for the E. coli enzyme (data not shown). No attempt was made to optimize this assay for the Streptomyces enzyme.

Other investigators who attempted to identify PTS activities in Streptomyces species focused on the glucosePTS in S. clavuligerus (Garcia-Dominguez et al., 1989) and S. griseus (Romano \& Margiotta, 1980). Their negative results were confirmed by our experiments. It should be noted that confirmatory experiments designed to detect immunological cross-reactivity using antibodies raised against purified Enzyme I or HPr yielded positive results when extracts derived from $S$. griseus, $S$. albus and $S$. lividans were examined (U. Wehmeier, personal communication).

Our inability to detect $\mathrm{HPr}(\mathrm{Ser})$ kinase activity in extracts derived from the three Streptomyces species examined under conditions that resulted in the facile detection of this activity in low-GC Gram-positive bacteria led us to believe that this protein, which plays an important regulatory role in low-GC Gram-positive bacteria (Reizer et al., 1993; Ye et al., 1994a, b), may not be present in Streptomyces species. However, other published results suggest that the PTS in Streptomyces may be involved in regulatory phenomena, such as catabolite repression (Hodgson, 1982, 1992; Delic et al., 1992; Angell et al., 1992) and the control of antibiotic biosynthesis (Distler $e t$ al., 1992). In one case, that of oleandomycin production by $S$. antibioticus, the highest level of antibiotic production was observed when fructose served as the carbon and energy source (Vilches et al., 1990). Furthermore, nutritional factors are known to influence antibiotic pro- duction in several cases (Cortes et al., 1986; Vilches et al., 1990). The presence of a complete PEP-dependent PTS suggests that one or several of the PTS proteins may interact directly with other enzymes, and thereby control their activities, or they may function catalytically to phosphorylate target proteins, thereby acting as a protein kinase system. Both possibilities have been demonstrated for other bacteria (Saier, 1993).

The discovery of a fructose-specific PTS in Streptomyces species as well as our inability to detect an $\mathrm{HPr}$ (Ser) kinase leads to the possibility that components of the PTS function in Streptomyces to regulate carbon metabolism, secondary metabolite biosynthesis, antibiotic excretion and/or differentiation by novel mechanisms, dissimilar from those currently recognized in enteric and low-GC Gram-positive bacteria. Further studies will be required to elucidate the role(s) of the PTS in regulatory phenomena in the industrially and medically important bacterial genus Streptomyces.

\section{ACKNOWLEDGEMENTS}

We wish to thank Pat Solenberg, Alexandra Alves, Udo Wehmeier and Christian Hoischen for helpful suggestions and discussions. Mary Beth Hiller provided expert assistance in the preparation of this manuscript. This work was supported by Public Health Service grants 5RO1 AI 21702 and 2RO1 AI 14176 from the National Institute of Allergy and Infectious Diseases and a grant from the Eli Lilly Corporation. Friedrich Titgemeyer was supported in part by a fellowship from the Alexander von Humboldt Foundation of Germany.

\section{REFERENCES}

Angell, S., Schwarz, E. \& Bibb, M. J. (1992). The glucose kinase gene of Streptomyces coelicolor A3(2): its nucleotide sequence, transcriptional analysis and role in glucose repression. Mol Microbiol 6, 2833-2844.

Baltz, R. H. \& Seno, E. T. (1988). Genetics of Streptomyces fradiae and tylosin biosynthesis. Annu Rev Microbiol 42, 547-574.

Borkovich, K. A. \& Simon, M. I. (1991). Coupling of receptor function to phosphate-transfer reactions in bacterial chemotaxis. Methods Enzymol 200, 205-214.

Bradford, M. M. (1976). A rapid and sensitive method for the quantitation of microgram quantities of protein utilizing the principle of protein-dye binding. Anal Biochem 72, 248-254.

Chater, K. F. (1990). The improving prospects for yield increase by genetic engineering in antibiotic-producing streptomycetes. Bio/ Technology 8, 115-121.

Chater, K. F. \& Hopwood, D. A. (1989). Antibiotic biosynthesis in Streptomyces. In Genetics of Bacterial Diversity, pp. 129-150. Edited by D. A. Hopwood \& K. F. Chater. London: Academic Press.

Chater, K. F. \& Hopwood, D. A. (1993). Streptomyces. In Bacillus subtilis and Other Gram-positive Bacteria, pp. 83-99. Edited by A. L. Sonenshein, J. A. Hoch \& R. Losick. Washington, DC: American Society for Microbiology.

Cortes, J., Liras, P., Castro, J. M. \& Martin, J. F. (1986). Glucose regulation of cephamycin biosynthesis in Streptomyces lactamdurans is exerted on the formation of $\alpha$-aminoadipyl-cysteinyl-valine and deacetoxycephalosporin C synthase. J Gen Microbiol 132, 1805-1814.

Delic, I., Robbins, P. \& Westpheling, J. (1992). Direct repeat sequences are implicated in the regulation of two Streptomyces 
chitinase promoters that are subject to carbon catabolite control. Proc Natl Acad Sci US A 89, 1885-1889.

Deutscher, J. \& Saier, M. H., Jr (1983). ATP-dependent protein kinase-catalyzed phosphorylation of a seryl residue in HPr, a phosphate carrier protein of the phosphotransferase system in Streptococcus pyogenes. Proc Natl Acad Sci US A 80, 6790-6791.

Distler, J., Mansouri, K., Mayer, G., Stockmann, M. \& Piepersberg, W. (1992). Streptomycin biosynthesis and its regulation in streptomycetes. Gene 115, 105-111.

Garcia-Dominguez, M., Martin, J. F. \& Liras, P. (1989). Characterization of sugar uptake in wild-type Streptomyces clavuligerus, which is impaired in glucose uptake, and in a glucose-utilizing mutant. J Bacteriol 171, 6808-6814.

Geistlich, M., Losick, R., Turner, J.R. \& Rao, R. N. (1992). Characterization of a novel regulatory gene governing the expression of a polyketide synthase gene in Streptomyces ambofaciens. Mol Microbiol 6, 2019-2029.

Grenier, F. C., Reizer, J., Waygood, E. B. \& Saier, M. H., Jr (1985). Evidence for covalently cross-linked dimers and trimers of Enzyme I of the Escherichia coli phosphotransferase system. J Bacteriol 163, 243-247.

Hodgson, D. A. (1980). Carbobydrate utilization in Streptomyces coelicolor $A 3(2)$. PhD thesis, University of East Anglia, Norwich, UK.

Hodgson, D. A. (1982). Glucose repression of carbon source uptake and metabolism in Streptomyces coelicolor A3(2) and its perturbation in mutants resistant to 2-deoxyglucose. J Gen Microbiol 128, 2417-2430.

Hodgson, D. A. (1992). Differentiation in actinomycetes. In Prokaryotic Structure and Function: a New Perspective, pp. 407-440. Edited by S. Mohan, C. Dow \& J. A. Cole. Cambridge: Cambridge University Press.

Hoischen, C., Reizer, J., Dijkstra, A., Rottem, S. \& Saier, M. H., Jr (1993). Presence of protein constituents of the Gram-positive bacterial phosphotransferase regulatory system in Acholeplasma laidlawii. J Bacteriol 175, 6599-6604.

Hong, S.-K., Kito, M., Beppu, T. \& Horinouchi, S. (1991). Phosphorylation of the AfsR product, a global regulatory protein for secondary-metabolite formation in Streptomyces coelicolor A3(2). J Bacteriol 173, 2311-2318.

Hopwood, D. A. (1988). Towards an understanding of gene switching in Streptomyces, the basis of sporulation and antibiotic production. The Leeuwenhoek Lecture, 1987. Proc R Soc Lond B 235, 121-138.

Ikeda, H., Seno, E. T., Bruton, C. H. \& Chater, K. F. (1984). Genetic mapping, cloning and physiological aspects of the glucose kinase gene of Streptomyces coelicolor. Mol \& Gen Genet 96, 501-507.

Ishizuka, H., Horinouchi, S., Kieser, H. M., Hopwood, D. A. \& Beppu, T. (1992). A putative two-component regulatory system involved in secondary metabolism in Streptomyces spp. $J$ Bacteriol 174, 7585-7594.

Kundig, W. \& Roseman, S. (1971). Sugar transport. II. Characterization of constitutive membrane-bound Enzymes II of the Escherichia coli phosphotransferase system. J Biol Chem 246, 1407-1418.

LiCalsi, C., Crocenzi, T. D., Freire, E. \& Roseman, S. (1991). Sugar transport by the bacterial phosphotransferase system. Structural and thermodynamic domains of Enzyme I of Salmonella typhimurium. $J$ Biol Chem 266, 19519-19527.

Martin, J. F. \& Demain, A. L. (1980). Control of antibiotic biosynthesis. Microbiol Rev 44, 230-251.

McCarthy, A. J. \& Williams, S. T. (1992). Actinomycetes as agents of biodegradation in the environment - a review. Gene 115, 189-192.

Miller, J. H. (1972). Experiments in Molecular Genetics. Cold Spring Harbor, NY: Cold Spring Harbor Laboratory.

Mitchell, W. J., Reizer, J., Herring, C., Hoischen, C. \& Saier, M. H., Jr (1993). Identification of a phosphoenolpyruvate: fructose phosphotransferase system (fructose-1-phosphate forming) in Listeria monocytogenes. J Bacteriol 175, 2758-2761.

Mosher, R. H. \& Vining, L. C. (1992). Antibiotic resistance. In Encyclopedia of Microbiology, vol. 1, A-C, pp. 97-106. Edited by J. Lederberg. San Diego: Academic Press.

Nagaso, H., Saito, S., Saito, H. \& Takashashi, H. (1988). Nucleotide sequence and expression of a Streptomyces griseosporus proteinaceous alpha-amylase inhibitor (HaimII) gene. J Bacteriol 170, 4451-4457.

Novotna, J. \& Hostálék, Z. (1985). Phosphorylation of hexoses in Streptomyces aureofaciens: evidence that the phosphoenolpyruvate: sugar phosphotransferase system is not operative. FEMS Microbiol Lett 28, 347-350.

Parr, T. R., Jr \& Saier, M. H., Jr (1992). The bacterial phosphotransferase system as a potential vehicle for the entry of novel antibiotics. Res Microbiol 143, 443-447.

Postma, P., Lengeler, J. \& Jacobson, G. R. (1993). Phosphoenolpyruvate:carbohydrate phosphotransferase systems of bacteria. Microbiol Rev 57, 543-594.

Pries, A., Priefert, H., Kruger, N. \& Steinbuchel, A. (1991). Identification and characterization of two Alcaligenes eutrophus gene loci relevant to the poly( $\beta$-hydroxybutyric acid)-leaky phenotype which exhibit homology to $p t s H$ and $p t s I$ of Escherichia coli. $J$ Bacteriol 173, 5843-5853.

Reizer, J., Novotny, M. J., Hengstenberg, W. \& Saier, M. H., Jr (1984). Properties of ATP-dependent protein kinase from Streptococcus pyogenes that phosphorylates a seryl residue in $\mathrm{HPr}$, a phosphocarrier protein of the phosphotransferase system. J Bacteriol 160, 333-340.

Reizer, J., Peterkofsky, A. \& Romano, A. H. (1988a). Evidence for the presence of heat-stable protein $(\mathrm{HPr})$ and ATP-dependent $\mathrm{HPr}$ kinase in heterofermentative lactobacilli lacking phosphoenolpyruvate: glycose phosphotransferase activity. Proc Natl Acad Sci US A 85, 2041-2045.

Reizer, J., Saier, M. H., Jr, Deutscher, J., Grenier, F., Thompson, J. \& Hengstenberg, W. (1988b). The phosphoenolpyruvate:sugar phosphotransferase system in Gram-positive bacteria: properties, mechanism, and regulation. CRC Crit $\mathrm{R} e v$ Microbiol 15, 297-338.

Reizer, J., Sutrina, S. L., Saier, M. H., Jr, Stewart, G. C., Peterkofsky, A. \& Reddy, P. (1989). Mechanistic and physiological consequences of $\mathrm{HPr}(\mathrm{ser})$ phosphorylation on the activities of the phosphoenolpyruvate: sugar phosphotransferase system in Grampositive bacteria: studies with site-specific mutants of HPr. EMBO J 8, 2111-2120.

Reizer, J., Reizer, A., Saier, M. H., Jr \& Jacobson, G. R. (1992a). A proposed link between nitrogen and carbon metabolism involving protein phosphorylation in bacteria. Protein Sci 1, 722-726.

Reizer, J., Reizer, A. \& Saier, M. H., Jr (1992b). A new subfamily of bacterial ABC-type transport systems catalyzing export of drugs and carbohydrates. Protein Sci 1, 1326-1332.

Reizer, J., Romano, A. H. \& Deutscher, J. (1993). The role of phosphorylation of $\mathrm{HPr}$, a phosphocarrier protein of the phosphotransferase system, in the regulation of carbon metabolism in Gram-positive bacteria. J Cell Biochem 51, 19-24.

Romano, A. H. (1986). Microbial sugar transport systems and their importance in biotechnology. Trends Biotechnol 4, 207-213.

Romano, A. H. \& Margiotta, E. (1980). In Abstracts of the $2 n d$ ASM 
Conference on Genetics and Molecular Biology of Industrial Microorganisms, abstract no. 16.

Sabater, B. \& Asensio, C. (1973). Transport of hexoses in Streptomyces violaceoruber. Eur J Biochem 39, 201-205.

Sabater, B., Sebastian, J. \& Asensio, C. (1972). Identification and properties of an inducible mannokinase from Streptomyces violaceoruber. Biochim Biophys Acta 284, 406-413.

Saier, M. H., Jr (1989). Protein phosphorylation and allosteric control of inducer exclusion and catabolite repression by the bacterial phosphoenolpyruvate:sugar phosphotransferase system. Microbiol Rev 53, 109-120.

Saier, M. H., Jr (1993). Regulatory interactions involving the proteins of the phosphotransferase system in enteric bacteria. $J$ Cell Biochem 51, 62-68.

Saier, M. H., Jr \& Reizer, J. (1992). Proposed uniform nomenclature for the proteins and protein domains of the bacterial phosphoenolpyruvate: sugar phosphotransferase system. J Bacteriol 174, 1433-1438.

Saier, M. H., Jr, Feucht, B. U. \& Hofstadter, L. J. (1976). Regulation of carbohydrate uptake and adenylate cyclase activity mediated by the enzymes II of the phosphoenolpyruvate:sugar phosphotransferase system in Escherichia coli. J Biol Chem 251, 883-892.

Saier, M. H., Jr, Feucht, B. U. \& Mora, W. K. (1977). Sugar phosphate: sugar transphosphorylation and exchange group translocation catalyzed by the Enzyme II complexes of the bacterial phosphoenolpyruvate:sugar phosphotransferase system. $J$ Biol Chem 252, 8899-8907.

Saier, M. H., Jr, Grenier, F. C., Lee, C. A. \& Waygood, E. B. (1985). Evidence for the evolutionary relatedness of the proteins of the bacterial phosphoenolpyruvate: sugar phosphotransferase system. $J$ Cell Biochem 27, 43-56.

Saier, M. H., Jr, Ye, J. J., Ramseier, T. M., Titgemeyer, F. \& Reizer, J. (1994). The bacterial phosphotransferase system: a multifaceted regulatory system controlling carbon and energy metabolism. In Pbosphate Metabolism in Microorganisms, pp. 189-194. Edited by A. Torriani-Gorini, E. Yagil \& S. Silver. Washington, DC: American Society for Microbiology (in press).

Schauer, A., Ranes, M., Santamaria, R., Guijarro, J., Lawlor, E., Mendez, C., Chater, K. \& Losick, R. (1988). Visualizing gene expression in time and space in the filamentous bacterium Streptomyces coelicolor. Science 240, 768-772.

Schoner, B., Geistlich, M., Rosteck, P., Jr, Rao, R. N., Seno, E., Reynolds, P., Cox, K., Burgett, S. \& Hershberger, C. (1992). Sequence similarity between macrolide-resistance determinants and ATP-binding transport proteins. Gene 115, 93-96.

Strickler, J. E., Berka, T. M., Gorniak, J., Fornwald, J., Keys, R., Rowland, J. J., Rosenberg, M. \& Taylor, D. P. (1992). Two novel Streptomyces protein protease inhibitors: purification, activity, cloning and expression. $J$ Biol Chem 267, 3236-3241.
Sutrina, S. L., Chin, A. M., Esch, F. \& Saier, M. H., Jr (1988). Purification and characterization of the fructose-inducible HPr-like protein, FPr, and the fructose-specific enzyme III of the phosphoenolpyruvate:sugar phosphotransferase system of Salmonella typhimurium. J Biol Chem 263, 5061-5069.

Titgemeyer, F. (1993). Signal transduction in chemotaxis mediated by the bacterial phosphotransferase system. J Cell Biochem 51, 69-74.

Titgemeyer, F., Walkenhorst, J., Cui, X., Reizer, J. \& Saier, M. H., Jr (1994). Proteins of the phosphoenolpyruvate-sugar phosphotransferase system in Streptomyces: possible involvement in the regulation of antibiotic production. Res Microbiol 145, 89-92.

Ueda, K., Miyake, K., Horinouchi, S. \& Beppu, T. (1993). A gene cluster involved in aerial mycelium formation in Streptomyces griseus encodes proteins similar to the response regulators of twocomponent regulatory systems and membrane translocators. $J$ Bacteriol 175, 2006-2016.

Vats-Mehta, S., Bouvrette, P., Shareck, F., Morosoli, R. \& Kluepfel, D. (1990). Cloning of a second xylanase-encoding gene of Streptomyces lividans 66. Gene 86, 119-122.

Vilches, C., Méndez, C., Hardisson, C. \& Salas, J. A. (1990). Biosynthesis of oleandomycin by Streptomyces antibioticus: influence of nutritional conditions and development of resistance. $J$ Gen Microbiol 136, 1447-1454.

Wu, L.-F., Tomich, J. M. \& Saier, M. H., Jr (1990). Structure and evolution of a multidomain, multiphosphoryl transfer protein: nucleotide sequence of the $f r u B(H I)$ gene in Rhodobacter capsulatus and comparisons with homologous genes from other organisms. $J$ Mol Biol 213, 687-703.

Ye, J. J., Reizer, J., Cui, X. \& Saier, M. H., Jr (1994a). ATPdependent phosphorylation of serine-46 in $\mathrm{HPr}$ regulates lactose: $\mathrm{H}^{+}$symport in Lactobacillus brevis. Proc Natl Acad Sci US A 91, 3102-3106.

Ye, J. J., Reizer, J., Cui, X. \& Saier, M. H., Jr (1994b). Inhibition of the phosphoenolpyruvate:lactose phosphotransferase system and activation of a cytoplasmic sugar-phosphate phosphatase in Lactococcus lactis by ATP-dependent metabolite-activated phosphorylation of serine-46 in the phosphocarrier protein, HP2. J Biol Chem 269, 11837-11844.

Ye, J. J., Neal, J. W., Cui, X., Reizer, J. \& Saier, M. H., Jr (1994c). Regulation of the glucose: $\mathrm{H}^{+}$symporter by metabolite-activated ATP-dependent phosphorylation of $\mathrm{HPr}$ in Lactobacillus brevis. $J$ Bacteriol 176, 3336-3344.

Ye, J. J., Reizer, J. \& Saier, M. H., Jr (1994d). Regulation of 2deoxyglucose accumulation in Lactococcus lactis vesicles by metabolite-activated, ATP-dependent phosphorylation of serine-46 in $\mathrm{HPr}$ of the phosphotransferase system. Microbiology 140 , 3421-3429.

Received 9 September 1994; accepted 30 September 1994. 